\title{
Perceiving nyiur melambai coastal ecotourism in Belitung, Indonesia
}

\begin{abstract}
Tanjung Kelayang Beach in Belitung Island is one of the top 10 destinations of government priority tourism today. It targeted to increase GDP to $8 \%$ in the next four years. In addition, it is targeted also working opportunities for 13 million people. On the other hand, Nyiur Melambai beach located on Belitung Island expected to help increase the local revenue and contribute economically to the local population. With the research of a qualitative and quantitative mixed mode, this study had conducted to disseminate a number of related respondents. Found some fundamental changes in the economic social aspects of local communities that is livelihoods. Previously, they are tin producers. Recently, they are turning to coastal ecotourism guides or a batik crafter. This concept has raised the economic needs of local governments and residents along the coast. The government needs financial resources in maintaining the quality of the coastal environment. Moreover, society needs economic contribution to sustain its life. In terms of the concept, it generated some business opportunity or work in the field.
\end{abstract}

Keywords: coastal ecotourism, social-economics, batik crafter
Volume 7 Issue 6 - 2018

\author{
Hengky SH \\ Universitas Bina Darma, Prasetiya Mandiri, SHINE Institute, \\ Indonesia
}

Correspondence: Hengky SH, Universitas Bina Darma, Prasetiya Mandiri, SHINE Institute, Indonesia, Email hengky_hajim@yahoo.com.au

Received: October 26, 2018 | Published: November 29, 2018

\section{Introduction}

The Minister of Tourism prioritizes promotions for 10 leading tourist destinations and a number of events next year. This is to support the target of 12 million foreign tourist arrivals in 2016. Meanwhile, it estimated that foreign tourists visit 10 million with an exchange target of US \$12 billion in 2015 . $^{1}$

Tanjung Kelayang Beach on the island of Belitung is one of the top 10 destinations of government priority tourism today. Previously, the Government had set up four Special Economic Zones, namely Tanjung Lesung, Mandalika, Morotai, and Tanjung Kelayang (Bangka Belitung) with each of the areas stipulated by government regulations. The Authority Body established through a legal umbrella of a presidential regulation, which managed by professionals. There is a business mechanism to ensure the progress of tourism in each destination. The minister said the tourism sector in 2019 should be able to contribute to the national GDP of $8 \%$, with foreign exchange generated 17.8 billion USD. In the same year, tourism had targeted to create employment opportunities in the field of tourism to 13 million people. The target of foreign tourists visiting is about 20 million. Nevertheless, he targeted about 275 million domestic tourist movements towards the country. However, tourism competitiveness index Indonesia became 30th ranked. ${ }^{2}$

On the other hand, Indonesia is the world's largest producer of tin ore, producing about $80 \%$ of the world's tin ore. The area of metal contributors that needed in formation of this industrial component is on the island of Bangka. This study aims to respond to the priority program targets of tourism ministers in their efforts to contribute to national GDP of $8 \%$ and perceiving Nyiur Melambai coastal ecotourism in Belitung.

\section{Literature review}

Ecotourism planning in this century requires good coordination between tourism industry managers, tourists and natural resources. In addition, to meet the demands of tourists, they need to gain a better understanding of their activities during coastal travel and reduce the impact on these activities. ${ }^{3-7}$

Recently, the concept of ecotourism in the context of coastal tourism is useful for protecting the habitats of vulnerable marine animals in capture. The concept reminded the need for conservations to protect these animals in coastal communities. ${ }^{7}$ The program can also support coastal landscape conservation efforts that increase economic contribution to the region through sustainable coastal tourism programs. ${ }^{9-12}$ Tourism along the coastline has more directed at presenting the beauty of coastal landscapes and managing businesses that visit coastal resources and trying to mitigate negative environmental impacts. ${ }^{6,13}$

Coastal-tourism (CE) to safeguard negative environmental impacts. The trick is to increase the knowledge of tourists about the fragility of the environment. This program has done by showing the relationship between ecology and economy. The realization of the program implemented in the form of cooperation between local communities, local authorities, and tourists. This valuable information supports programs and businesses that are engaged in the tourism business on an ongoing basis. ${ }^{14,15}$

Eco-tourist beaches like to visit to natural coasts. They became a beach-lovers community that became their main destination in traveling. Today, fishing is another hobby and recreation favored by them. As time goes by, demand for coastal ecotourism are increasing steadily. Therefore, the conservation of the coastal environment becomes the key competitiveness of CE in the future. Many things that make the tourists enjoy a natural beach atmosphere and clean. These factors determine the quality of tourism that includes water quality, landscape, coastal wetland protection and bay, and fisheries. The traditional approach to management along the coastline generally 
increases the environmental carrying capacity of coastal erosion. Such combined controls can control the erosion and conservation of coastal areas naturally. ${ }^{6,7,16-18}$

Furthermore, the understanding of coastal communities on $\mathrm{CE}$ continues to increase as they are engaged in socially integrated social tourism development programs. Mass tourism and ecotourism complement each other needs of the two segments of tourists in the context of the development. Both type of tourism work together on a different scale. Both from the approach to national and international tourism policy. In addition, these two tourism activities help the integration of tourism activities. On the other hand, ecotourism products are also worth doing that integrated into a broader tourism sector and development program. Both program to create sustainable livelihoods for coastal communities. ${ }^{9-11,17}$

Many efforts to integrate $\mathrm{CE}$ to support sustainable tourism development policies. Many community-based ecotourism projects had been successfully implemented by the help of the development community. This suggests that the expertise of tourism developers linked to opportunities and barriers in addressing the cultural issues of local communities. In addition, the limited capacity of transportation and marketing efforts became the constraints on ecotourism development. Therefore, all policymakers needed an agreement in realizing their mission. ${ }^{19-22}$

The potential for coastal areas plays an important role in regional development. A settlement of coral reefs - anglers have had the appeal to coastal and cultural ecotourism. This attraction is an indicator of the increase in tourists visiting from year after year. However, the anglers are generally still low-income. Development of fishery-based ecopond settlements is required. Various social and cultural activities in the fishing zones can increase their economic income. Similarly, the development of trading activities, management and sales of marine products can maintain the preservation of socio-cultural, economic and environmental development. This indicates that the zone of settlement activity is associated with CE zones, as they support each other. $^{8-10,15-17,20,23-27}$

However, as above mention, $\mathrm{CE}$ is various social and cultural ecotourism activities, maintain the preservation of socio-cultural, economic activities in the fishing zone, development of fishery-based eco-pond settlement, management and sales of marine product, and maintain environmental development. ${ }^{8-11,15,17,20,25}$

\section{Methodology}

The research of this qualitative and quantitative mixed mode ${ }^{27}$ had conducted in Belitung from October 2014- October 2015 (Figure 1) on Nyiur Melambai beach (NMB). Randomly 270 questionnaires were distributed among purposive techniques to ecotourists, tour guides, bus drivers, fishermen, traditional food traders, restaurant and hotel staff, parking attendants, souvenir merchants, tourism associations, local government, Bangka Belitung Culture and Tourism, and relevant agencies. This quantitative and qualitative research had integrated into the analysis of the combination of both in practice. This study uses structured and quantitative quantitative interviews in cross-sectional design, while on the qualitative side of semi-structured interviews.

The data collected were tabulated using content analysis ${ }^{28,29}$ based on the concept of CE. Then, the data had processed by triangulation technique. This had done to direct the consistency of observations by comparing the results of open interviews and secondary data. ${ }^{30}$
The topics of the interview include the interests and opinions or views of the respondents. The interviewer's situation offsets these interviews results. In summary, content analysis results from CE explore dissent, post each attribute, frequency is calculated, and argue that there is and targeting performance. ${ }^{16,17,31-33}$

The concept includes efforts to build various social and cultural ecotourism activities, maintain the preservation of socio-cultural, economic activities in the fishing zone, development of fishery-based eco-pond settlement, management and sales of marine product, and maintain and develop coastal environment. ${ }^{8-11,15,17,20,25}$

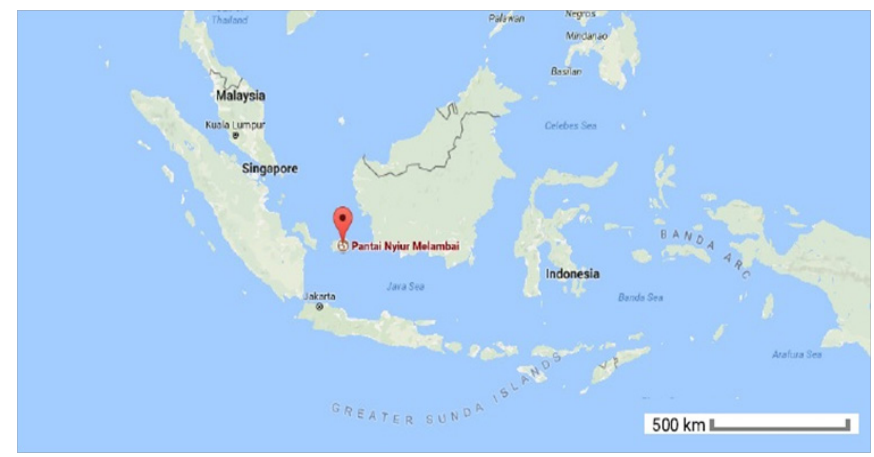

Figure I Nyiur melambai coast.

\section{Results and Discussion}

The results of the study (Table 1) indicated that the current condition of NMB almost meet the requirements of $\mathrm{CE}(\mathrm{K}=0.5815)$. The most dominant factor of ecotourism is the diversity of social and cultural activities (0.2102) that support ecotourist activities during their visit to the area. The next dominant aspect is the economic activity in the fishing area (0.1783). From management to sales of marine products are also quite dominant (0.1656). Maintaining of coastal environment development still needs to be improved (0.1592). Similarly, the development of fishery-based pond based fisheries needs to be further improved (0.1465). Maintain the preservation of socio-cultural also needs had to be considering of strengthening the training and development of each coastal sub-region of the grassroots of coastal communities $(0.1401)$.

NMB is located in Lalang Village, Manggar District, East Belitung City, Bangka Belitung Province. In terms of social and cultural ecotourism activities, this beach has better known by the name of Lalang Beach in accordance with the name of his village. The beach is one of the popular attractions in East Belitung City.

Belitung beach toured is located about $1.5 \mathrm{~km}$ from downtown Belitung Timur. Entering the tourist area, they look pretty bigwords "Nyiur Melambai". White sand beached had ready to greet and welcome the arrival of the tourists. The blowing winds hit their faces and made the leaves of pine trees waving and inviting them to dance and mingle with the natural atmosphere of the beach that looks beautiful and fascinating.

NMB has an elongated coastline with white sand and pine rows that make the atmosphere on this beach shady, cool and beautiful. In terms of economic activities in the fishing zone, the conditions of gently wave's beach water are relatively not too big. It made this beach safe for tourists doing their activities on the beach. They can swim or fish and also just take a walk around the beach or sit back 
on the benches that are available equipped with a large umbrella. This facility provided quite well. The visitors can sit comfortably and enjoying the charm of beautiful beach ecotourism without having to fear the heat of the sun. Some people are fishing and colorful fishing boats they can see here.

Besides swimming, the beach is still having a coastal landscape of unadorned giant granite. In terms of maintaining and developing coastal environment, here the traveler can relax behind the cool sea firs. This iconic replica of these beasts is one of the attractions of this beach. Tourists who often used these replicas areas as a background in taking their photos. In addition, of course, backed by beach landscape is almost without the stones are interspersed. Facilities on the beach are complete, ranging from pedestrian paths of the shore, a rest area, toilets, and praying room. ${ }^{34}$

Everything had built with a colorful pattern, just like the colors of the rainbow. In terms of maintaining the preservation of socio-cultural, the other activities they could possibly do are visiting this coast are beach volleyball, indoor soccer and rock climbing. Sports facilities are indeed available in this coastal attraction Belitung East. They can also see local art festivals that often held here. In the morning is the right time for them visited this coast. They can witness the amazing sunrise or sunrise. This sunrise tourist visiting this Belitung tourist attraction very eagerly awaited moment by. No wonder when the morning, many visitors are coming to the beach on a weekend or holiday season.

There are many places to eat and drink ready to entertain them with their friends or family in this tourist area. In terms of management and sales of marine products, enjoying the charm of beach tourism, usually the tourists want to feel the traditional food. They can find many food stalls and drinks not far from the parking lot. Entering the beach, tourists had greeted with a view of the sea pine trees neatly lined up. Underneath, there are various replicas of the iconic replicas of Belitung Island, mainly Belitung Timur, including a replica of Satam stone and a colorful coffee mug of Manggar as a city of 1001 coffees shops.

The Satam stone may be the only stone that could only find in the island of Belitung. To get this stone is not easy, even more to be a craft. Usually the artisans get it from the tin miners that found the stone by chance from the bowels of the earth with a depth of 50meters. They also accidentally found it from a water-suction pump pipe that directed to a place to separate sand and lead. The term Satam had taken from the language of Chinese citizens residing in this island. SA means sand, and TAM means bile. Therefore, Satam means sand bile. Newertheless, the island's indigenous people mean Satam is a black stone.

One of the functions of coral reefs is as a physical protective barrier from the pressure in waves and storms. As coral reefs damaged or destroyed, the coast eroded by wave impacts that threaten residential areas and local land use patterns. In terms of development of fisherybased eco-pond settlement, referring to the general provisions of zoning regulations of coastal zones shall be set 50meters from the highest tide point of land in the area of settlement designation or on coastal areas equipped with retaining walls shall permitted to support facilities buildings Non-permanent and temporary tourism. In addition, buildings related to traditional fishing activities, aquaculture and wharves, coastal surveillance, and coastal protection buildings from abrasion.
Table I Existing Performance of Coastal Ecotourism in Nyiur Melambai

\begin{tabular}{llll}
\hline Existing performance of coastal ecotourism & Value & \% Freq \\
\hline Various social and cultural ecotourism activities & 33 & 0,2102 \\
Maintain the preservation of socio-cultural & 22 & 0,1401 \\
Economic activities in the fishing zone & 28 & 0,1783 \\
Development of fishery-based eco-pond settlement & 23 & 0,1465 \\
Management and sales of marine product & 26 & 0,1656 \\
Maintain and develop coastal environment & 25 & 0,1592 \\
\hline
\end{tabular}

Kappa Coefficient $=K_{1}=0,58 I 5$

The results of performance expectation tabulation from CE (Table 2) indicate the need to improve various social and cultural ecotourism activities. There was a second priority shift from economic activities in the fishing zone to management and sales of marine products. Also shifted the third priority from management and sales of marine product to economic activities in the fishing zone. Subsequently, there was a fourth shift of hope from maintaining and develop coastal environment to the development of fishery-based eco-pond settlement. Further, there is a shift in the fifth priority of development of fisherybased eco-pond settlement of economic activities in the fishing zone. Finally, there is a sixth priority shift from maintaining the preservation of socio-cultural to maintain and develop coastal environment.

Table 2 Expected Performance of Coastal Ecotourism in Nyiur Melambai

\begin{tabular}{lll}
\hline Existing performance of coastal ecotourism & Value & \% Freq \\
\hline Various social and cultural ecotourism activities & 36 & 0,1837 \\
Maintain the preservation of socio-cultural & 33 & 0,1684 \\
Economic activities in the fishing zone & 31 & 0,1582 \\
Development of fishery-based eco-pond settlement & 32 & 0,1633 \\
Management and sales of marine product & 34 & 0,1735 \\
Maintain and develop coastal environment & 30 & 0,1531 \\
\hline
\end{tabular}

Kappa Coefficient $=\mathrm{K}_{2}=0,7259$

The results of the tabulation of stakeholder's overall performance expectations indicate the need for enhanced management and sales of marine products (Table 2). Bangka Island, the typical food of the area has cultural valuesthat contain local wisdom and must be preserve. Since the dominant region of these islands is the oceans, the main characteristic of the food community related to marine products or processed marine products. In addition to, there is also food from the plantation that is around the coast. Types of food include seafood such as dried seafood, dried fish, sea worms or dried Wak-Wak, dried shrimp, Gung-gung snail, sea cucumber, shark fin, Rusip, Kecalok, Pekasem. Then various seafood processed products such as Keretek, Kempelang, Crackers, Sambalingkung, Terasi, Brain - brain, Empek Empek, Lakso, Bergo and Pantiau.

In addition to the typical food characterized by seafood, there are also various types of traditional pegs such as Martabak Bangka or Hok Lo Pan, Rintak Sagu, Gandus, and Rangai Cake. Besides, there are True Cake, Bugis Cake, Jongkong Cake and a typical Dodol called Lempok Cempedak or Durian. Then known also the natural result of bitter Honey and original Sweet Honey from Bangka Island Bee Island 
with its own taste and efficacy, very well for health. Furthermore, the famous traditional cuisine is the famous Yellow Lempah.

This spice is a typical food and a main food in the family and community. It is also a food in traditional and religious ceremonies. In the Pangkalpinang community tradition called Sepintu Sedulang, everything done together, usually before doing a big job or celebration or after working together, the Yellow Spice dish is the main side dish cooked and eaten together.

Besides, it has also presented seasoning sauce comprising three Paste or shrimp paste, chilli and salt as a seasoning. The three materials used as complementary side dishes. From the spices, they used with the composition of the three materials above illustrating that the people of Bangka Belitung are a society that is practical and not complicated. For complementary food is usually in the afternoon on the Cake Cookies to eliminate thirst or thirst as a snack of coffee and tea companion.

\section{Environmental problem}

Tin of the island of Belitung has exploited since the Dutch era, or about 300years ago. The people of the island remain poor until now. The prices of basic commodities are still expensive. Almost all commodities have obtained by bringing in from outside the island. Recently, the environmental damage caused by tin mines on the island is increasingly dire. In recent years, tin mining does not make on a land. It does at sea. This is the result of the depletion of terrestrial exploited areas. It was getting worse. The damage to sea is difficult to control. Moreover, the excavated holes hidden in the bottom of the water. PT Timah Tbk as the largest official company also began to move its mining priorities to offshore areas. The ship is operated just less than 4 nautical miles from the shoreline and a depth of 5-20meters. It could predict that in the next few years tin mining activities on the coast will become more widespread.

The economic impact on tin mining is not worth the ecological impact it generates. Most of the lead gains go into the pockets of big businesspersons and lead smugglers. Some residents that work as illegal miners or known as the Conventional Mine only become pawn of the tin miners. By using a makeshift equipment, the threat to life is always threatening. More than 32-people buried and died in the pits of the people's mines in 2012. The majority of coastal residents are: forests and land devastated, polluted water, fish - coral reefs damaged in this island,. Karen's dozens of residents from various circles that are members of the People's Reject Forum on the Marine Mine on the island held a peaceful action. The action refused a sea mine on the island that took place in the tourist area Nyiur Nyambur Beach. Really dilemma expected good environmental performance, was disturbed by activities tin mine. Therefore, this study recommends local governments to Enhanced management - sales of marine products based on eco-tourism concepts that are environmentally friendly and contribute economically to local communities and stakeholders.

\section{Suggestion: enhanced management and sales of marine products}

There are a number of improvable economic contributions and conserved the coast environment. It done by developing a business coastal portfolio based on the concept of ecotourism as a batik craft, and marine products. Besides, it would be conserved a sea fish and seagrass beds, and decorative fish. However, they would change their culture of fish consumption.

\section{Batik craft}

In addition to culinary ecotourism, ecotourists could find the potential for batik craft ecotourism in this beach. The head of the Family Welfare Movement Family of Belitung Timur District explained that they since June 2012 managed the management of batik of East Belitung regency, Sanggar Batik that is located near the residence of Belitung Timur Regent. The participants of batik fashion show followed by bachelor and women Belitung Timur. These activities had driven by the District Government through the Department of Culture and Tourism and in collaboration with the Esmod Jakarta model school.

The regent of Belitung Timur Regency stated that by doing such activities to change the mindset of the local community. They usually work or work as tin collectors - anglers also have skills in batik business. With this skill, it expected that coastal communities will also have the opportunity developing and manage their batik skills. He stated that with many enthusiasts from tourists to Batik Belitung Timur, this is one of the community motivation to manage batik better. Second, He expected the students that drop out of school. The society can take opportunity to make batik for the new generation creating new design of batik. Therefore, we need help from the local government and with the relevant agencies. The people are more motivated in preparing to work like batik for batik. He also explained that ecotourism is the key to post tin. After the tin does not exist, the community's life remains prosperous. Craft ecotourism had done by a batik. He also invited and supported the people that are interested to explore this activity to come to the batik studio.

\section{Marine products}

Strengthening the management of marine products, in terms of $\mathrm{CE}$, mangrove ecosystems and coral reefs need to maintain. There is a biota of Trochus niloticus, Turbo sp, Pteria penguin. The types of mollusks that used for a meat are Anadara spp, Hyppospus hypoppus, and Tridacna squamosal. The reforestation and conservation of mangrove forests is one of the steps taken by the South Coastal Government to minimize the impact on coral reef and mangrove forest damage. A damage to coral reefs around 80percent in 2013, 30 percent of mangrove forests will be difficult dammed. The extent of damage to coral reefs and mangrove forests in the area is already at an alarming condition. Thanks to the supervision and awareness of the fishing community along with conservation assistance, the damage had minimized.

The cultivation programmed that has done explained through preservation and supervision expected to reduce the damage of coral reefs and mangroves. Conservation efforts by not damaging and regrowing coral reefs through technological engineering. In 2015, 15hectares of coastal reforestation activities have been conducted with sea cucumber planting - mangrove. Its four locations are on Ampiangparak and Sungaisirah beach in Sutera Subdistrict, Sumedang and NMB in the coastal Ranah district.

The existence of coral reefs is an important thing that had preserved for the sustainability of marine ecosystems. The community of anglers asked no to longer do the destruction, as the coral reefs do not exist anymore caused the fish are extinct. The impact is on the anglers 
themselves, as it is difficult to get fish and gradually shut down the source of the economy. The move has done since 2012, with the aim that coral reefs that have damaged it can recovered. The remaining mangrove or mangrove forests are no more than 400hectares. Coastal communities are also already cutting down the remaining land for temporary use. Hence on the remaining land area, the forest is no longer dense, even it threatened with extinction. The youth of the indigenous village of Ampik Parak, Pesisir Selatan Regency, green the beach by planting pine trees and mangrove timber. Maintaining the environment is the responsibility for all of us, including youth or young generation. The environment is damaged then there also a risk. In order to protect the environment, local youth did reforestation of Amping Parak Beach. The youth grouped calling itself the Amul Parak Environmental Care Youth Warriors planted pine trees and mangroves along the coast of the area. The activity was born in Amping Parak youth to protect the environment especially along the coast to reduce environmental damage and other risks of the threat to disasters coming from the sea.

Amping Parat Warriors Parak' cares for the environment to plant seeds of pine marine - mangrove wood on the beach area of 1.7 hectares will be used as a turtle conservation site. Special pine tree seedlings planted as many as 2500 stem and mangroves as many as 25thousand stems. For Amping Parak, the government provides seed assistance of 27,500 stems consisting of sea pine and mangrove. In the South Coast, there is an area of 15 hectares of land done reforestation by the central government. The land had spread on the beach Nyiur Melambai Ranah coastal district. ${ }^{35}$

\section{Sea fish and seagrass beds}

Enhancing economic contribution would be done by conserved a number of seagrass species on this island. There are Enhalus acoroides, Cymodocea rotundata, Thallasia hemprichi and Halophila minor. Around the seagrass ecosystem there are usually herbivores such as baronang fish, green turtle (Chelonia mydas), and hawksbill turtle (Eretmochelys imbricata). Types of macroalgae in the territorial waters: Caulerpa taxipola, Sargasum spp, Padina gymnospora, Caulerpa spp Subergogia mollis. Most of the catches are Cokkol, Kakap (Lutjanus spp), Bloating, Calamari, Pelagic small, Grouper (Serrandae), Lobster (Panulirus spp). Both effort would help on improving marine ecotourism that would contribute economic to local community along the coastline. They would be a tourist guide or rent the equipment for diving activities.

\section{Decorative fish}

Marine Service - Fisheries East Belitung encourages the production of ornamental fish as an export commodity. The seriousness begins with the signing of a memorandum of understanding between local governments and companies exporters of ornamental fish and freshwater fish from Jakarta. In addition, they also formally send 17000 ornamental fishes prepared for export markets through partner companies. They hope the memorandum of understanding will generate many regional benefits, especially post mining. At that-time the agreement was signed $\mathrm{MoU}$ with CV Cahaya Baru Jakarta. New Light accommodates all these products, such as ornamental fish, or marine fish including ornamental coral.

The most promising potential for development of the fisheries sector is ornamental fish and freshwater fish. Simply put, the former mining excavations had used as breeding pools. The most realistic, currently developed is freshwater ornamental fish. This area has more than 200 mine excavations that utilized. The ornamental fish that developed in this area is Discus type. This type is an export commodity that is in great demand by almost all countries. Currently being encouraged to do the spawning fish. After that, they can sell it to the public or in export. As evidence of the seriousness, they have been doing coahcing community groups prepared to meet the needs of ornamental fish export. They have built four communities for the production of this fish. The results had exported abroad such as Malaysia, Singapore and Europe. ${ }^{36}$

\section{Culture of fish consumption}

Increased consumption of fish more easily realized if supported by all components. This year, a number of children are involved in promoting the movement to populate eating fish. This activity had expected to encourage the interest in children eating fish that can have a positive impact on improving their intelligence, strength and health. Cooking Competition of all provincial level fish had centered on NMB at the end of 2015. Through fish cooking, contest the creation of new creations in serving, fish processing. In addition, the economy of the people of Bangka Belitung improved by exporting an ornamental fish to Europe. It had expected to create a diversity of fish-based food menu. The opening up of domestic fisheries product market opportunities too. This activity is an effort to increase fish consumption. This activity also aims to increase the interest in fish consumption of the community and introduce the diversity of cuisine made from raw fish. Efforts to realize food security and nutrition become a necessity for a nation, especially Indonesia. ${ }^{37}$

Mardini Restaurant Manggar Subdistrict became the First Winner of Professional Fish Cooking Competition in East Belitung Regency in 2015. The competition had organized by the Department of Marine and Fisheries District. The event that took place at the Beach, Manggar Sub-district was followed by 8 teams from restaurants and cooks from all of this regency. By serving dishes such as, Fish Grouper Stem, Sus Burger Shrimp, Fish Patel Nugget, Red Macked Fish Tenggiri Soup, Mackerel Fish Pudding, and Yogourh, The restaurant succeeded in making the jury amazed and entitled to get trophy, charter and coaching money.

A chair of the jury of cooking competition explains all participants' cuisine judged based on five criteria namely, taste, presentation, creativity, hygienic, and its nutritional value. In addition, the jury also divides the value of three categories of cuisine, namely, family cuisine, toddlers and snacks, the champion must meet all these criteria. The champion involved in cooking contest at a higher level. This is to emphasize the importance of improving nutrition to children especially during the development of brain development and development of mental blueprints of children's mental and physical health. In this festival, the committee also held a bazaar of processing fishery products, awareness raising, Catfish catching competitions, and ornamental Cupang fish contest.

\section{Conclusion}

The results of this study indicate the socio-economic-cultural transformation of local communities based on the concept of CE. This concept is useful to balance economic development and conservation of coastal environments. On the other hand, there is a dilemma between local government and central government policy. They targets increasing international and national tourist arrivals. It appears on the results of the current performance tabulation that need for diversity 
of social and cultural activities to support ecotourist activities during their visit to the area. The next dominant aspect is the economic activity in the fishing area. In contrast, there are opportunities for economic development of coastal communities, especially anglers that concentrate more on fishing tourism activities that can fish and make money. Besides, the boat had hired for fishing activities. Furthermore, the management of ornamental fish also contribute greatly if managed professionally. There are even businesspersons that export ornamental fish to various countries in Asia and Europe.

The local community needed other business opportunities for culinary ecotourism activities at the time ecotourist's move there. The typical food of coastal area based on marine fish is excellent for tourists that enjoying the natural beauty of coastal. Local people's culture becomes a slim attraction for them. In addition, batik craft ecotourism is also beneficial to coastal communities whose free time had allocated to batik activities.

\section{Implication}

The concept of coastal eco-tourism can respond to the socioeconomic needs of coastal communities that can contribute economically to them. Indirectly, this activity contributes economically to the local government that used for coastal environmental conservation. In addition, this concept creates new fieldwork especially for coastal communities from both ecotourism and culinary ecotourism sectors.

\section{Limitation of study}

Time and personal limitations in interviewing requiring some funds to carry out this research. There are other research opportunities in the field of landscaping, zoning, and marketing strategies of batik crafts and specialty foods of the region.

\section{Acknowledgments}

The author like to thanks to SHINE Institute that participated in distributing the questionnaires to the respondent, as well as to the editors and reviewers that have supported in the process of publication of the journal.

\section{Conflicts of interest}

Author declares that there is no conflicts of interest.

\section{References}

1. Fitriani E. Promosi Diprioritaskan ke 10 Destinasi Unggulan Wisata, Berita satu. 2015.

2. Poerwanto E. Menpar: 10 Featured Tourism Destinations Have Different Problems, Tourist business. 2016.

3. Attemene P, Eguavoen I. Coastal ecotourism in The Gambia: Effects of sustainability communication on environments and rural livelihoods. ZEF Working Paper Series. 2017.

4. Ban J, Ramsaran RR. An Exploratory Examination of Service Quality Attributes in the Ecotourism Industry. Journal of Travel \& Tourism Marketing. 2016;34(1):132-148.

5. Conway T, Cawley M. Defining ecotourism: evidence of provider perspectives from an emerging area. Journal of Ecotourism. 2016;15(2): $122-138$.

6. Halim HS. Improving coastal tourism business competitiveness: Using ecotourism's concept to explore to potential of coastal tourism business Pandeglang and Serang Districts. Banten. West-Java. Indonesia. International Journal of Business and Social Science. 2011;2(11). 87-90.

7. Halim HS. Excogitated Coastal Tourism Competitiveness by Implementing Eco-tourism in Anyer, Banten, Indonesia. International Journal of Marines Science. 2014;4(7):74-81.

8. Fitzgerald LA, Stronza AL. In Defense of the Ecotourism Shield: A Response to Geffroy et al. Trends in Ecology \& Evolution. 2016;31 (2):94 95.

9. Hengky SH. Beholding Tanjung Pesona Coastal-ecotourism in Bangka Islands, Indonesia. Business and Economic Research. (2017a);7(2): 102117.

10. Hengky SH. Gazing Coastal Ecotourism in Morotai Islands, Indonesia. Environmental Management and Sustainable Development. (2017b);6(2):144-157.

11. Hengky SH. Probing Coastal Eco-Tourism in Pasir Putih Beach, Indonesia. Business and Management Horizons. (2017c);5(1):1-11.

12. Hengky SH. Scrutinizing Coastal Ecotourism in Gili Trawangan, Indonesia. International Journal of Marine Science. (2017d);7(25):247-259.

13. Boley BB, Green GT. Ecotourism and natural resource conservation: the 'potential' for a sustainable symbiotic relationship. Journal of Ecotourism. 2016;15(2):122-138.

14. Buckley R. Ecotourism: Principles and practices. CABI. 2009;218-252.

15. Honey M. Ecotourism and Sustainable Development, Second Edition: Who Owns Paradise? Washington DC. Island Press. 2008;28-33.

16. Chien MC. An empirical study on the effect of attractiveness of ecotourism destination on experiential value and revisit intention. Applied Ecology and Environmental Research. 2016;15(2):43-53.

17. Krause A, Weir E. Ecotourism: Management, Development and Impact, Nova Science Publishers. Hauppauge, New York. 2011.

18. Pace NL, Morgan N. Living Shorelines: Eroding Regulatory Barriers to Coastal Resilience. Natural Resources \& Environment. 2017;31(3): 44-47.

19. Cobbinah PB. Contextualising the meaning of ecotourism. Tourism Management Perspectives. 2015;16:179-189.

20. Lloret J, Riera V. Evolution of a Mediterranean Coastal Zone: Human Impacts on the Marine Environment of Cape Creus. Environ Manage. 2008;42(6);977-988.

21. Picard D. Making ecotourism sustainable: refocusing on economic viability. Lessons learnt from the "Regional strategic action plan for coastal ecotourism development in the South Western Indian Ocean". Journal of Sustainable Tourism. 2015;23(6):819-837.

22. Sakata H, Prideaux B. An alternative approach to community-based ecotourism: a bottom-up locally initiated non-monetised project in Papua New Guinea. Journal of Sustainable Tourism. 2013;21(6):880-899.

23. Almeyda AM, Broadbent EN, Wyman MS, et al. Ecotourism impacts in the Nicoya Peninsula, Costa Rica. Int J Tourism Res. 2010;12: 803-819.

24. Diamantis D. Ecotourism and sustainability in Mediterranean islands. Thunderbird Int'l Bus Rev. 2000;42:427-443.

25. Kelkit A, Celik S, Eșbah H. Ecotourism potential of Gallipoli Peninsula historical national park. Journal of Coastal Research. 2010;26(3): 562568.

26. Porter BA, Orams MB, Lück M. Surf-riding tourism in coastal fishing communities: A comparative case study of two projects from the Philippines. Ocean \& Coastal Management. 2015;116:169-176. 
27. Rusli Santosa HR, Soemarno I. Coastal ecotourism-based developmen for fishermen settlement in Labuan Bajo, Donggala, Central Sulawesi. International Journal of Development Research. 2015;5(08):5215-5221.

28. Bryman A. Integrating quantitative and qualitative research: how is it done?. Qualitative research. 2006;6(1):97-113.

29. Gottschalk LA. Content Analysis of Verbal Behavior: New Findings and Clinical Applications, Routledge. 2013;19-22.

30. Henderson K. Dimensions of Choice: A Qualitative Approach to Recreation, Parks, and Leisure Research. Venture. State College. Australia. 1991.

31. Marwick DP, Uniger CH. The Sample Survey, Theory and Practice, Mc Graw Hill Book Co, New York. 1975.

32. Loperena CA. Honduras is open for business: extractivist tourism as sustainable development in the wake of disaster? Journal of Sustainable Tourism. 2016;25(5):618-633.
33. Nouri J, Danehkar A, Sharifipour R. Evaluation of ecotourism potential in the northern coastline of the Persian Gulf. Environment Geology. 2008;55(3):681-686.

34. Nuzula NI, Armono HD, Rosyid DM. Management of Baluran National Park Resources for Coastal Ecotourism Based on Suitability and Carrying Capacity. Applied Mechanics and Materials. 2017;862:161-167.

35. Law D. Nyiur Melambai, Beautiful Beach without Stone Granite in Belitung, Detik Travel. 2016.

36. Junisman. Youth Coastal South Green Beach with Pine. 2015.

37. Msi. DKP East Belitung Encourage Export of Ornamental Fish. 2015

38. Kominfo D. Governor: Create New Creation of Fish Processing. 2015 